\title{
Leadership Role of School Superintendents in Saudi Arabia
}

\author{
Mohamed A. Almannie ${ }^{1}$ \\ ${ }^{1}$ Professor Education Administration, College of Education, King Saud University, Saudi Arabia \\ Correspondence: Mohamed A. Almannie, Professor Education Administration, College of Education, King Saud \\ University, Saudi Arabia.
}

Received: February 25, 2015

Accepted: March 17, 2015

Available online: April 21, 2015

doi:10.11114/ijsss.v3i3.780

URL: http://dx.doi.org/10.11114/ijsss.v3i3.780

\begin{abstract}
This study examines the practice of school superintendents in Saudi Arabia in five roles as seen by education supervisors within school district offices. The purpose of the study is to examine the leadership of school superintendents in these five roles: work environment, rules and regulations, implementation of technology, accountability, and professional development of the education supervisors in school districts. The study sample consists of 276 education supervisors working in 30 school districts. The study reveals that the respondents (education supervisors) perceived leadership roles enacted to a low degree for the five roles. The final results show that school superintendents' leadership needs to be developed in order to provide a high quality of education, by improving the selection of superintendents and offering better training in the five roles. The Ministry of Education should decentralize major decisions to school superintendents so that they can be active in leading change and perform leadership roles in their school districts.
\end{abstract}

Keywords: leadership role, education office, school district, education supervisor, Saudi Arabia

\section{Introduction}

The education system in Saudi Arabia started in 1925 under the Directorate of Education, which changed to the Ministry of Education in 1954. Girls' education was officially established in 1960 with a separate agency, and the two systems unified in 2003 under the Ministry of Education (Ahmed Rumi-Amer Suwadani, 2013). There have been rapid changes due to the continuous development of technology and competitive markets around the world, and highly qualified educational leaders are needed to meet the challenges posed by these changes. The development of education depends on local school district officials, for they have close supervision of education. The education system in Saudi Arabia has continued its quantitative and qualitative development through consecutive development plans. There is a remarkable growth, by all standards, as a result of the policy of free education for all citizens. The number of students enrolled in public education has reached over 5 million.

According to the U.S.-Saudi Arabian Business Council, the upward trend of budgetary allocations highlights the Saudi government's conviction that education is the cornerstone of sustained economic development, as it enhances human capital and knowledge, which are both essential ingredients for economic growth and social cohesion. Public spending for education is estimated at 5.7 percent of the country's gross domestic product (GDP), comparable with the U.K. (5.3 percent), Germany (4.3 percent), and South Korea (4.2 percent). Yet, although the budget for education is increasing, the quality of education lags, as Saudi students do not rank highly on international examinations such as PISA.

The Ministry of Education decentralized major operational tasks to school districts. The director of a school district, called the "school superintendent" in many countries, is considered a very important position in the school system of Saudi Arabia. The director is responsible for the supervision and implementation of policy, planning, and programs in the school district.

Although major steps have been taken toward the decentralization of management of education, an analysis of the Organizational Guide for the Administration of School Districts in Saudi Arabia (Ministry of Education, 2012) shows that the tasks and duties of the director of the school district are more administrative in nature rather than geared toward the development of local schools.

With all the efforts and high budgets to provide free formal education for both men and women and increasing adult literacy rates, school leaders face new challenges, many of which are the result of advances in information and 
communication technologies, and increased globalization and competition among nations, which has created a demand for skills that Saudi education needs to promote (Tatweer, 2010).

Therefore, school superintendents face challenges because of their limited leadership roles for the implementation of policies and regulation. Most of them are not prepared to carry out leadership responsibilities for the development of education in their school district. The development of learning is not embedded in the educational system of school districts, for school superintendents tend to act more as mangers than educational leaders.

Tatweer (2010) indicated that the education system in the Kingdom of Saudi Arabia faces new challenges, many of which are the result of advances in information and communication technologies, and increased globalization and competition among nations, which has created demands for skills that Saudi education needs to promote.

Research shows that schooling centers around two basic functional domains: teaching and learning, and organizing for teaching and learning. Over time, these functions became largely segregated by role, with teachers assuming nearly all responsibility for the former and administrators taking responsibility for the latter (Prestine \& Nelson, 2005). The case in Saudi Arabia is that organizing for teaching and learning overcomes the domain of teaching and learning, for decentralization and accountability are not fully embedded in the system of the school district. The literature shows that in school-based management (SBM), decentralizing decision making to the local level brings decision making closer to the people so that their preferences can be better reflected in policy (Besley \& Coate, 2003); however, the schools in Saudi Arabia and many developing countries cannot be described as using SBM because school districts are not involved in the development of learning process at local schools. Moreover, stakeholders' involvement in the development of schools is very limited.

Al-omrani (1992) suggested that secondary school principals in Jordan be assigned a special role in the education administration arena. Principals should also be more involved in the educational decision-making process and should be trained to provide better quality of education. Botha (2007, p. 39) indicated that effective SBM encourages schools to become self-managing systems with improved performance that pursue long-term school effectiveness in a changing environment. SBM includes stakeholders' active involvement and participation in the self-management of schools, which ultimately has an influence on decision making; therefore, educators should realize the importance of stakeholders' involvement in education and value their ideas and contributions.

Most analysts argue that more successful districts are able to balance centralized expectations, accountability, and resource management with school-level flexibility support that enables school personnel to adapt district goals and plans to the circumstances of their schools with appropriately individualized district support (Fullan et al., 2004; Hightower et al., 2002).

In order for SBM to be effective in Saudi Arabia, there is a need for further decentralization for school districts, as well as more authority for school superintendents to be active in the development process of schools and to provide a better environment for engaging stakeholders in school participation (Botha, 2007). The issue in Saudi Arabia is that, although decentralization is recognized and preferred by officials in the Ministry, in practice, there is no balance between centralization and decentralization.

The Ministry of Education established the General Agency of School Districts to raise the standards of school districts in terms of performance indicators, which are now implemented on a low scale in some school districts. Yet other major steps still need to be taken toward the professional development of school superintendents, decentralization of education, and more effective outcomes in education. Therefore, the objective of this study is to shed light on the leadership role of school superintendents for the purpose of achieving better quality of education at the local level.

The structure of school districts in Saudi Arabia consists of three levels: 13 school districts are considered "general directorates," which report directly to the Deputy Minister of Education. The general school districts form several intermediate-level school districts called "administrations of education," which report to the general directorate, and there are also small school offices of education districts called "education offices," which report to the administration of education.

An earlier study about education districts (Al-Salloom, 1974) indicated that there is a relationship between school district size in Saudi Arabia and the administrative power and authority exercised in the district: the smaller the school district is in both area and number of schools, teachers, and students, the more administrative power and authority is exercised; conversely, the larger the school district is in area and size, the less administrative power and authority. Recent data show that school districts have more authority and responsibilities, but the organization of teaching and learning still higher than the domain of teaching and learning.

Anderson, Mascall, Stiegelbauer, and Park (2012) demonstrated variability in district orientation and the capacity to understand school needs to improve performance; their findings suggest that the process of professional learning 
communities (PLCs) helped change school districts by creating high-performing collaborative teams, developing a district-wide sense of efficacy, and emphasizing the use of data to improve education. However, in order for this to occur, the superintendent must be a highly visible actor in the process of change and must be decidedly engaged in the majority of visioning and mission-setting activities.

Horton and Martin (2013) reported that board members, administrators (both central office and building-level), and teachers agreed that PLCs provided staff with additional tools to positively influence student achievement. For this to happen, the superintendent must be actively engaged in the processes. Evidence also suggests that the process of PLCs has helped change school districts by creating high-performing collaborative teams, developing a district-wide sense of efficacy, and emphasizing the use of data to improve instruction. However, in order for this to occur, the superintendent must be a highly visible actor in the process of change and must be decidedly engaged in the majority of visioning and mission-setting activities.

\section{Education Supervisors}

An education supervisor is defined by the Ministry of Education as an expert in his/her field of study who helps teachers develop professional skills and solve educational problems they face, in addition to improving teaching methods to guide the educational process in the right direction (MOE, 1998),

Education supervisors play an important role in the development of education in a school district. The superintendent cannot perform his/her duties in the development of education without the education supervisor's evaluation reports following visits to schools; therefore, the development of education depends mainly on the education supervision office of the school district.

The main selection criteria for education supervisors are as follows:

1. Hold at least a B.S. degree in education with a minimum of a "C" average

2. Have working experience in teaching for at least 4 years

3. Have an evaluation of "excellent" or higher in teaching for the last 4 years

4. Have the ability to communicate and influence others

5. Follow new innovations in the relevant field.

\section{Qualifications of School Superintendents}

The school district superintendent is the essential element for the development of schools and is considered the face of the district. Although superintendents in Saudi Arabia are most responsible for the success of the district, they are not accountable for failures. Superintendents spend most of their daily work time on administrative and paper matters rather than on the development of education and future planning. The minimum qualification for school superintendents in government schools is a B.S. degree; a Master's degree or Ph.D. is not required.

There are 303 international schools in Saudi Arabia, and their school superintendents have higher qualifications than those in public schools, as they are required to have an advanced degree in education (e.g., a Ph.D. or Ed.D.) and meet the following criteria (International Schools Group [ISG], 2012):

- A minimum of five years demonstrated success in leading an educational organization to greater levels of achievement and success

- Experience in the development of organizational capacity

- Strong knowledge of the U.S. curriculum

- International experience preferred

Superintendents are also required to have personal qualifications such as "integrity, fairness, transparency and trustworthiness," to "promote a collaborative working style," and to be "problem solver[s] with proven track record[s] of successful leadership."

Superintends of public schools obtain professional development through conventional methods and training sessions locally and abroad. Although the Ministry of Education spends millions of dollars on professional development for superintendents, school principals, and teachers, there are no measures of the output of training programs on a national level. Hess and Kelly (2005) indicated that the current procedures and management of education cannot produce exceptional leaders with unique skill sets to serve as effective school superintendents. In order to lead today's schools, principals must have the capacity to lead. The King Abdullah Project for the Development of Public Education in Saudi Arabia (Tatweer, 2012) aims to develop public education in general and leadership in schools in particular by providing professional development to teachers and school administrators. However, the project is still in its initial stages, and there is more concentration on resource management than on the development of leadership capacity to improve education at the school level. 
Superintendents can act as educational leaders by focusing on professional development related to instructional issues and basing principal evaluations on instructional improvement. The superintendent's role can be strengthened by having universities revise their leadership preparation programs to provide district leaders with practical knowledge and skills (Lashway, 2003). Districts appear to have relatively weak processes and systems for finding, sharing, and using relevant research (Cooper \& Levin, 2013). The effectiveness of the management of Resource Program Centers at the school district level is moderate (Omran, 2010).

Alsobiae (2009) investigated the important leadership roles of administrators of education (superintendents) in Saudi Arabia. They are as follows: 1) motivating staff in the school district, 2) practicing distributed leadership, 3) building and developing strategies in collaboration with staff, 4) developing strategies for the development of the school district, 5) developing infrastructure for change management, and 6) building a culture for change. Preparation, competencies, and dispositions enhance effective leadership. Therefore, effectiveness must begin with a quality preparation program that offers opportunities for participants to understand theory as well as experience the practical aspects of leading a school (Green, 2013). Abaalkhail (2013) emphasized that universities and other educational institutes should plan and allocate required budgets for the implementation and maintenance of all aspects of quality in education.

\section{Problem of the Study}

The idea of the study originated from the author teaching a doctoral level course on the Administration of Education Districts. There are many aspects to be investigated about the leadership roles of superintendents. The role of superintendents has become increasingly demanding and requires a new type of leadership. Algarni and Male (2014) concluded that to implement pedagogical leadership appropriately, leaders in the Saudi educational context need, in addition to flexibility and autonomy, to be offered more training programs, which should focus on important areas that have a direct influence on learning and teaching, development, group dynamics, organizational theory, and various teaching approaches; give leaders more freedom; and encourage their creativity to exercise their skills and influence appropriately in the context for the benefit of the learning environment. Therefore, the study focused on five areas related to the learning environment that have relative importance for leadership roles in changing schools in the districts. These roles relate to the following: work environment, participation and communication, technology implementation, professional development of education supervisors, and accountability.

The new accountability system focuses on performance rather than compliance with regulations. It is noticed that the role of superintendents in Saudi Arabia consists of more managerial tasks and paperwork than educational development of the schools in the district. This study is concerned with examining this issue. The study will answer the following questions:

1. What is the leadership role of superintendents in facilitating the work environment and collaboration and participation in decision making?

2. What is the leadership role of superintendents in technology implementation and accountability?

3. What is the leadership role of superintendents in the professional development of education supervisors?

\section{Research Method}

The study used two instruments. A questionnaire was designed to examine five leadership roles of superintendents. The questionnaire was distributed to education supervisors from 30 school districts in Saudi Arabia, with the sample consisting of 276 education supervisors. The other instrument consisted of interviews with 22 education supervisors attending the training program at the College of Education at King Saud University in the spring semester 2015. Education supervisors were chosen for this study because their tasks and duties are mainly for the improvement of school education, and they can give better perceptions of the leadership roles for the development of education at the district level than other district employees.

Twenty-two education supervisors were interviewed about superintendents regarding the following:

1. the relation between the tasks and duties of school superintendents and their leadership role

2. the five roles investigated in the study

The interviews supported the results of the questionnaire:

The participants answered each item of the questionnaire by indicating either a high or low degree of agreement, and their responses were analyzed by frequencies and percentage.

Table 1 indicates that the education supervisors generally had low agreement that the factors were present in the work environment of their school district: $77 \%$ of respondents expressed a low degree of agreement that there were clear policies for motivating education supervisors, and $70 \%$ expressed a low degree of agreement that there were clear standards for the evaluation of education supervisors. 
Table 1. Work Environment in the School District Office

\begin{tabular}{lcccc}
\hline \multicolumn{1}{c}{ Degree of Agreement } & & & \\
\hline & $\begin{array}{c}\text { High } \\
\text { Degree }\end{array}$ & $\%$ & $\begin{array}{c}\text { Low } \\
\text { Degree }\end{array}$ & $\%$ \\
\hline Clear policy and procedures & 121 & 44 & 155 & 56 \\
Clear vision in the office & 121 & 44 & 155 & 56 \\
Participation in the vision and mission & 117 & 42 & 159 & 58 \\
Clear policies for motivating education supervisors & 63 & 23 & 213 & 77 \\
Clear standards for evaluation of education supervisors & 82 & 30 & 194 & 70 \\
\hline
\end{tabular}

Table 2. Participation and Communication in the School District Office

\begin{tabular}{|c|c|c|c|c|}
\hline \multicolumn{5}{|c|}{ Degree of agreement } \\
\hline & High degree & $\%$ & low degree & $\%$ \\
\hline There is effective communication in school district office. & 178 & 64 & 98 & 36 \\
\hline There is electronic communication with education supervisors. & 181 & 66 & 95 & 34 \\
\hline $\begin{array}{l}\text { Education supervisors participate in the decision making of the } \\
\text { office. }\end{array}$ & 82 & 30 & 194 & 69 \\
\hline $\begin{array}{l}\text { The plans and suggestion of education supervisors are taken into } \\
\text { consideration. }\end{array}$ & 107 & 39 & 169 & 61 \\
\hline Distinguished education supervisors are motivated. & 91 & 33 & 185 & 67 \\
\hline $\begin{array}{l}\text { The school district office makes use of feedback from education } \\
\text { supervisors for the development of schools. }\end{array}$ & 83 & 30 & 193 & 70 \\
\hline
\end{tabular}

Table 2 shows that although there was a relative higher communication degree of agreement about the items in relation to the school district office, there was low degree of agreement that education supervisors participated in decision making (69\%), that their feedback was taken into consideration for the development of schools (70\%), and that distinguished education supervisors were motivated (67\%). Further, 69\% of the respondents expressed a low degree of agreement that they participated in decision making.

Table 3. Technology implementation

\begin{tabular}{|c|c|c|c|c|}
\hline \multicolumn{5}{|l|}{ Degree of agreement } \\
\hline & High degree & $\%$ & $\begin{array}{c}\text { Low } \\
\text { degree }\end{array}$ & $\%$ \\
\hline $\begin{array}{l}\text { Integration of technology into the curriculum and management is part of } \\
\text { the office plan. }\end{array}$ & 133 & 48 & 143 & 52 \\
\hline $\begin{array}{l}\text { The office depends on many technology resources for the development } \\
\text { creativity of the employees. }\end{array}$ & 77 & 28 & 199 & 72 \\
\hline There is an internal network to be used by education supervisors. & 106 & 38 & 170 & 62 \\
\hline Email is used for communication between education supervisors. & 209 & 76 & 67 & 24 \\
\hline WhatsApp is used for work duties. & 209 & 76 & 67 & 24 \\
\hline The office integrates technology into education supervision. & 155 & 56 & 121 & 44 \\
\hline
\end{tabular}

Table 3 shows that there was a relative low use of technology in school district offices and higher use of technology for WhatsApp and emails, which do not require high infrastructure and training. Most of the school districts did not have an internal network to be used by school supervisors.

Table 4. Professional Development of Education Supervisors

\begin{tabular}{ccccc}
\hline Degree of agreement & & & \\
\hline & High & $\%$ & Low & $\%$ \\
& degree & degree & \\
\hline
\end{tabular}




\begin{tabular}{|c|c|c|c|c|}
\hline $\begin{array}{l}\text { There is an adequate facility for the education supervisors to } \\
\text { engage in research activities. }\end{array}$ & 47 & 17 & 229 & 83 \\
\hline $\begin{array}{l}\text { There is motivation for employees who follow new trends in } \\
\text { education. }\end{array}$ & 80 & 29 & 196 & 71 \\
\hline There is encouragement for teamwork. & 130 & 47 & 146 & 53 \\
\hline $\begin{array}{l}\text { There is a yearly plan for the professional development of } \\
\text { education supervisors. }\end{array}$ & 72 & 26 & 204 & 74 \\
\hline $\begin{array}{l}\text { Training programs are designed for the professional } \\
\text { development of school principals and teachers. }\end{array}$ & 86 & 31 & 190 & 69 \\
\hline $\begin{array}{l}\text { Education supervisors are encouraged to use modern methods } \\
\text { in education. }\end{array}$ & 88 & 32 & 188 & 68 \\
\hline $\begin{array}{l}\text { Management of the office encourages education supervisors to } \\
\text { enroll in specialized training programs. }\end{array}$ & 116 & 42 & 160 & 58 \\
\hline
\end{tabular}

Table 4 shows that the majority of the education supervisors perceived low professional development in the school district.

Table 5. Accountability

\begin{tabular}{|c|c|c|c|c|}
\hline \multicolumn{5}{|l|}{ Degree of agreement } \\
\hline & $\begin{array}{l}\text { High } \\
\text { degree }\end{array}$ & $\%$ & $\begin{array}{c}\text { Low } \\
\text { degree }\end{array}$ & $\%$ \\
\hline There is a system of rewards for distinguished employees. & 44 & 16 & 232 & 84 \\
\hline Every employee in the office knows his/her duties and rights. & 88 & 32 & 188 & 68 \\
\hline There is fairness in distributing duties to education supervisors. & 110 & 40 & 166 & 60 \\
\hline $\begin{array}{l}\text { The office manager discusses performance with education } \\
\text { supervisors. }\end{array}$ & 99 & 36 & 177 & 64 \\
\hline Every employee in the office is accountable for his/her tasks. & 113 & 41 & 163 & 59 \\
\hline Evaluations based on standards are applied to all employees. & 83 & 30 & 193 & 70 \\
\hline
\end{tabular}

Table 5 shows that accountability is not implemented to a high degree in school districts, for the Ministry of Education did not embed it in the system of education in Saudi Arabia. Therefore, the superintendents cannot practice their roles as leaders without having employees accountable for their tasks.

\section{Discussion}

According to the King Abdullah Project for the Development of Public Education (Tatweer, 2012), there are major efforts to develop leadership at the school level in order to initiate SBM, but the developments are still in the initial stages and will be limited because the emphasis is still on the centralization of decisions, although there have been some positive developments toward decentralization, and more significantly than before the Tatweer project. The past decentralization reforms in Saudi Arabia connected directly to provide education for all and focused more on mobilizing resources than on improving instructional quality.

All attempts at the development of instruction and learning at public schools in Saudi Arabia are weak in moving responsibility to local districts. Superintendents of government schools still are not authorized to make decisions regarding the development of learning at schools because they lack leadership roles for change; moreover, motivation, employee motivation in decision making, feedback, and accountability are still practiced only to low degrees. The interviews with 22 education supervisors support the results of the study. In order for decentralization attempts giving decision making power to local school districts to be successful, there should be investment in professional training for school superintendents and principals in the five areas investigated in this study.

\section{Conclusion}

The survey of research shows that superintendents have leadership roles in the development of school districts, and this study reveals that the respondents indicated low degrees of agreement regarding all of the five roles investigated. The overall results indicate that education supervisors perceive the leadership role of school superintendents as low. This may be due to the centralized system of the Ministry of Education and lack of qualified leadership of school superintendents. 
There is a very important implication of the study for the development of school superintendents in all of the roles investigated (i.e., work environment at the school district, participation and communication, technology implementation, professional development of education supervisors and accountability). Therefore, training programs should be designed in these areas to provide increased leadership roles and develop the ability of school superintendents to lead changes in education at the district level.

\section{References}

Abaalkhail, M. (2013). The education quality model: Saudi and British perspectives on pillars of quality in education (Unpublished doctoral dissertation). Brunel University London, United Kingdom. Retrieved from http://bura.brunel.ac.uk/handle/2438/7655

Algarni, F., \& Male, T. (2014). Leadership in Saudi Arabian public schools: Time for devolution? International Studies in Educational Administration (Commonwealth Council for Educational Administration \& Management (CCEAM)), 42(3), 19, 28-29.

Al-omrani, A. M. A. (1992), Perception of superintendents, assistants of superintendents, and educational supervisors towards the role of the secondary school principal (Unpublished Master's thesis). Yarmouk University, Irbid, Jordan.

Al-Salloom Hamad, I. (1974). A study of the relationship of school district size and administrative practices in schools in Saudi Arabia (Unpublished doctoral dissertation). Oklahoma University, Norman.

Alsobiae, O. A. B. (2009). Leadership roles for administrators of education in light of the requirements of change management (Unpublished doctoral dissertation). University Umm Algura, Macca, Saudi Arabia.

Anderson, S. E., Mascall, B., Stiegelbauer, S., \& Park, J. (2012). No one way: Differentiating school district leadership and support for school improvement. Journal of Educational Change, 13(4), 403-430. http://dx.doi.org/10.1007/s10833-012-9189-y

Besley, T., \& Coate, J. (2003). Centralized versus decentralized provision of local public goods: A political economy analysis, Journal of Public Economics, 87(12), 2611-2637. http://dx.doi.org/10.1016/S0047-2727(02)00141-X

Botha, R. J. (2007). School-based management: Stakeholder participation and the impact of stakeholder values. Africa Education Review, 4(1), 28-41. http://dx.doi.org/10.1080/18146620701412126

Cooper, A., \& Levin, B. (2013). Research use by leaders in Canadian school districts. International Journal of Education Policy \& Leadership, 8(7). Retrieved from www.ijepl.org

Green, R. L. (2013). Response to the call for effective leadership in today's schools: Three essentials - preparation, competency, and dispositions. National Forum of Applied Educational Research Journal, 26(1- 2).

Hess, F. M., \& Kelly, A. P. (2005). Learning to lead? What gets taught in principal preparation programs. Retrieved from http://www.hks.harvard.edu/pepg/PDF/Papers/Hess_Kelly_Learning_to_Lead_PEPG05.02.pdf

Lashway, L. (2003). Journal Code: RIEAPR 2003 Entry Date: 2003 Accession Number: ED468515

Ministry of Education (2012). Organizational guide for the administration of school districts in Saudi Arabia.

Omran, G. M. (2010). Management effectiveness of Resource Program Centers in Irbid Governorate and its Role in Teacher's professional development from their point of view (Unpublished doctoral dissertation). Yarmuk University, Jordan.

Prestine, N. A., \& Scott, N. B. (2005). How can educational leaders support and promote teaching and learning? New conceptions of learning and leading in schools. In W. A. Firestone \& C. Riehl (Eds.), A new agenda for research in educational leadership (Critical Issues in Educational Leadership Series). New York and London: Teachers College, Columbia University.

Rumi, A., \& Suwadani, A. (2013). Glimpses of the march. Saudi Education during 90 Almarefh. Tatweer (2010). King Abdullah bin Abdulaziz Public Education Development Project. http://www.tatweer

Tatweer (2012). King Abdullah Project planning guide. Riyadh. U.S.-Saudi Arabian Business Council. The education sector in the Kingdom of Saudi Arabia. http://www.us-sabc.org/files/public/Education_Brochure.pdf

\section{(c) EY}

This work is licensed under a Creative Commons Attribution 3.0 License. 